"condition caused by an anaphylactic crisis of bonemarrow" (Bock ${ }^{1}$ ), has been cured with massive doses of folic acid by Gendel, Black and Stanbury ${ }^{2}$. The more spectacular results obtained in the treatment of macrocytic anæmia can be explained supposing that folic acid has much more specific action on the allergic blockage of erythropoietic tissue than on the allergic blockage of the leukopoietic one.

Clinica Pediatrica,

Vincenzo Traina Pavia.

${ }^{1}$ Daft, Ann. Nero York Acad. Sci., 48. 299 (1947). Bock, quoted by Storti in "Diagnostica Medica Uifferenziale".

"Gendel, J. Lab. and Clin. Med., 32, 139 (1947). Black, D. A. K., and Stanbury, S. W., Lancet, (i), 827 (1947).

\section{Presence of Histamine in Central Nervous System Extracts}

I $\mathrm{T}$ is well known that alcoholic or aqueous extracts of central nervous tissues (especially brain) lower the arterial blood pressure when injected intravenously into laboratory animals (dogs, cats, rabbits, etc.) ${ }^{\mathbf{1 , 2 , 3}}$. The chemical agent, or agents, of the pressor effect, however, have not yet been identified; studies by Vincent et al. ${ }^{3}$, Major and Weber ${ }^{1}$ and more recently are the same as extract $A$ but treated with basic lead acetate until no more precipitate was formed, centrifuged to eliminate the precipitate, and the lead from the supernatant removed by precipitation with sulphate and centrifugation. After neutralization, the activity of the extracts was tested by injection into the femoral vein of dogs anæsthetized with pentobarbitone, blood-pressure records being taken from the carotid artery. The histamine equivalent of the extracts was determined by comparing the effect on the arterial blood pressure of different concentrations of extract with similarly different concentrations of histamine solutions.

Similar results are obtained with acetone or trichloroacetic $^{7}$ extracts of brain. Extractions of the nervous tissues with ethyl ether did not yield active preparations. The extracts, after purification with basic lead acetate, which does not remove the depressor activity (contrary to the findings of Major and Weber ${ }^{1}$ ) were further fractionated by following the main lines of the procedure described by Best et al. ${ }^{8}$. The activity was carried down in both precipitations with phosphotungstic acid and silverbarium hydroxide, the depressor effect of the active fractions, as well as that of the original extract, being inhibited by benadryl.

\begin{tabular}{|c|c|c|c|c|c|}
\hline & $\begin{array}{l}\text { Histamine } \\
\text { equivalent of } \\
\text { the extracts } \\
(\mu \mathrm{gm} . / \mathrm{ml} .)\end{array}$ & $\frac{\text { gm. tissue }}{\text { ml. extract }}$ & $\frac{\mu \mathrm{gm} . \text { histamine }}{\mathrm{gm} . \text { tissue }}$ & $\begin{array}{c}\begin{array}{c}\text { Inhibition } \\
\text { respo } \\
\text { benadryl } \\
(1 \mathrm{mgm} . / \mathrm{kgm} .)\end{array} \\
\end{array}$ & $\begin{array}{l}\text { he depressor } \\
\text { es by : } \\
\text { atropine } \\
(0 \cdot 1 \text { mgm. } / \mathrm{kgm} .)\end{array}$ \\
\hline $\begin{array}{l}\text { Extract } A(0.09 \mathrm{ml}) \\
\text { Extract } B(0.125 \mathrm{ml} .) \\
\text { Equivalent histamine, } 4 \mu \mathrm{gm} \text {. } \\
\text { Extract } B_{8}(0.23 \mathrm{ml} .) \\
\text { Equivalent histamine, } 10 \mu \mathrm{gm} \text {. }\end{array}$ & $\begin{array}{l}45 \\
32 \\
43 \\
-\end{array}$ & $\begin{array}{l}2 \cdot 6 \\
2 \cdot 0 \\
- \\
4 \cdot 4 \\
\end{array}$ & $\begin{array}{l}17 \cdot 3 \\
16 \cdot 0 \\
\frac{9 \cdot 8}{-}\end{array}$ & $\begin{array}{l}26 \text { per cent } \\
25 " \Rightarrow \\
24 \text { " } \\
(3 \text { mgm. } / \mathrm{kgm} .) \\
67 \text { per cent } \\
71 ",\end{array}$ & $\begin{array}{c}{ }_{0}^{0 \text { per cent }} \\
-" \\
=\end{array}$ \\
\hline
\end{tabular}

Kwiatkowski ${ }^{4}$ having apparently discarded (or greatly minimized) the role of both histamine and choline in the pharmacological activity of the extracts. The object of this note is to present evidence that histamine is the main agent responsible for the depressor effect, and that central nervous system tissues, therefore, as well as many other tissues (liver, lung, skin, muscle, etc.) ${ }^{5}$, contain histamine.

To detect histamine in the extracts, we have used (as recently suggested by Loew et al. ${ }^{6}$ ) the new antihistamine drug benadryl, which in the dog inhibits almost specifically the action of histamine on the arterial blood pressure, approaching the degree of specificity displayed by atropine against acetylcholine. Therefore we tested in dogs the action of both benadryl and atropine on the effect of the extracts, and found that benadryl reduced in the same degree the depressor responses both to the extracts and to small doses of histamine, whereas atropine (in agreement with the results of earlier workers ${ }^{1,3}$ ) left unmodified the depressor response to the former.

The accompanying table summarizes the results of a typical experiment, the extracts having been prepared from ox, sheep, dog or rabbit brain, as follows. The fresh nervous tissue was minced, mixed with twice its volume of 96 per cent ethanol and left (with frequent stirring) either at $20^{\circ}$ or in the cold for 4-20 hours. The suspension was then pressed through a thin cloth, and the brain matter extracted once more in the same way. First and second filtrates were collected and evaporated in vacuo below $50^{\circ}$; the residue was spun off and the bulky precipitate of denatured proteins and lipids discarded (supermatant : extract $A$ ). Extract $B$ (from ex. $A$ ) and extract $B_{1}$
Full details of this work will be published elsewhere. We are indebted to Dr. J. J. Izquierdo for measuring the potency of some of our extracts.

V. H. CICARDo

A. O. M. Stoppani

Centro de Investigaciones Tisiológicas, Hospital Tornú.

Instituto de Fisiología,

Facultad de Ciencias Médicas, Buenos Aires. Sept. 25.

${ }^{1}$ Major, R. H., and Weber, C. H., J. Pharmacol., 37, 367 (1929). ${ }^{2}$ Schäfer, E. A., and Moore, B., J. Physiol., 20, 1 (1896).

${ }^{3}$ Vincent, S., Curtis, F. R., and Leeds, B. C., Lancet, i, 1142 (1926).

4 Kwiatkowski, H., J. Physiol., 102, 32 (1943).

s Guggenheim, M., "Die Biogene Amine", 362 (S. Karger, Basel, 1940). - Loew, E. R., MacMillan, R., and Kaiser, M. E., J. Pharmacol., 88,
229 (1946).

'Barsoum, G. S., and Gaddum, J. H., J. Physiol., 85, 1 (1935). B Best, C. H., Dale, H. H., Dudley, H. W., and Thorpe, W. V., $J$.
Physiol., 62 , 397 (1927).

\section{Isolation from Acid-Fast Bacteria of a Growth- Factor for Mycobacterium johnei and of a Precursor of Phthiocol}

Mycobacterium johnei will not grow on plain egg medium; but Twort and Ingraham ${ }^{1}$ demonstrated that good growth could be ensured by the addition of acid-fast bacteria or products extracted from them with organic solvents. Egg medium containing 1 per cent dried Myco. johnei has been used for many years to cultivate the organism.

We have now isolated from Myco. phlei a com. pound capable of promoting vigorous growth of 